DOI https://doi.org/10.30525/978-9934-588-81-5-1.15

\title{
ЕФЕКТИВНІСТЬ КОМПЛЕКСНОЇ ТЕРАПІЇ З ВИКОРИСТАННЯМ ПРЕПАРАТУ КАРДІОМЕТАБОЛІЧНОЇ ДІЇ У ДІТЕЙ $З$ НЕКОМПАКТНОЮ КАРДІОМІОПАТІЕЮ ЛІВОГО ШЛУНОЧКА
}

\section{Герасимова О. В.}

кандидат медичних наук, доиент кафедри педіатрії № 1

Вінницький національний медичний університет імені М. I. Пирогова

Процюк Т. Л.

доктор медичних наук,

професор кафедри педіатрії № 1

Вінницький національний медичний університет імені М. I. Пирогова

Капітан T. В.

кандидат медичних наук,

доиент кафедри педіатрії № 1

Вінницький національний медичний університет імені М. I. Пирогова

\section{Пугач М. М.}

кандидат медичних наук,

асистент кафедри педіатрії № 1

Вінницький національний медичний університет імені М. І. Пирогова

Процюк Л. О.

кандидат медичних наук,

асистент кафедри загальної гігієни та екології

Вінницький національний медичний університет імені М. I. Пирогова м. Вінниия, Украӥна

Актуальність. За останні роки спостерігається зростання частоти кардіоміопатій серед дитячого населення, що пов'язане не тільки 3 істинним збільшенням цієї патології, але і з широким впровадженням сучасних високоінформативних інструментальних методів дослідження серця [5, с. 22]. Серед первинних кардіоміопатій у дітей особливе місце займає некомпактна кардіоміопатія (НКМШ) лівого шлуночка $[2$, с. 12]. Вона відноситься до рідкісних, маловивчених кардіоміопатій та характеризується надмірним розвитком трабекул з формуванням глибоких лакун, які сполучені 3 порожниною лівого шлуночка [3, с. 134; 7 с. 519]. Неспецифічність клінічної картини є причиною того, що переважна більшість випадків НКМП лівого шлуночка не 
діагностується вчасно, а діагноз встановлюється при появі стійких ознак серцевої недостатності, шлуночкових аритмій та тромбоемболічних ускладнень [4, с. 182; 6, с. 1840]. Несприятливий прогноз та висока летальність при НКМП лівого шлуночка визначають необхідність іiі розпізнавання на ранніх стадіях і диференційованого підходу до лікування, залежно від тяжкості стану дитини з використанням сучасних методів лікування [1, с. 67].

Мета дослідження. Провести оцінку ефективності кардіометаболічної терапії у дітей з некомпактною кардіоміопатією лівого шлуночка.

Матеріали та методи дослідження. Для досягнення мети проведений ретроспективний аналіз 41 історії хвороб дітей з кардіоміопатіями, які знаходились на стаціонарному лікуванні в педіатричному відділенні. Основна група включала 22 дітей 3 некомпактною кардіоміопатією лівого шлуночка. Усі діти залежно від виду терапевтичного лікування були поділенні на дві терапевтичні групи: 1 група (n-12) - діти з НКМП ЛШ, яким до традиційної терапії (ІАПФ, діуретики, антитромболітики) додавали L-карнітин у дозі 50 мг/кг на добу за 30 хвилин до вживання їжі, розділивши дозу в три прийоми. Тривалість лікування становила 3 місяця, 2 група (n-10) - діти з НКМП ЛШ, які отримували лише традиційну терапію (ІАПФ, діуретики, антитромболітики).

В ході роботи використані такі методи дослідження: клінікоанамнестичні, інструментальні (ЕКГ, ЕхоКГ, ДЕхоКГ, МРТ серця), аналітико-статистичні.

Результати дослідження та їх обговорення. При клінічному обстеженні діти з НКМП лівого шлуночка пред'являли різноманітні скарги. Необхідно відмітити, що серед них частіше спостерігались неспецифічні скарг на швидку втомлюваність, яка спостерігалась у $14(63,63 \pm 10,24 \%)$ дітей, головний біль - у 11 (50,00+10,66 \%), затримку фізичного розвитку - у $9(40,9 \pm 10,48 \%)$ дітей. Специфічні клінічні симптоми, такі як серцебиття - у $7(31,81 \pm 9,92 \%)$ дітей, задишка у $6(27,27 \pm 9,49 \%)$ та запаморочення - у $6(27,27 \pm 9,49 \%)$ дітей зустрічалися майже $з$ однаковою частотою. Серед загальної кількості дітей $4(18,18 \pm 8,22 \%)$ відчували біль в ділянці серця, а $3(13,63 \pm 7,31 \%)$ дітей мали в анамнезі втрату свідомості. Скарги на кашель спостерігались у $2(9,09 \pm 6,12 \%)$ дітей, переважно старшого віку, в той час, як у дітей раннього віку при об'єктивному обстеженні був виявлений акроціаноз у $3(13,63 \pm 7,31 \%)$. Рідко діти скаржились на відчуття перебоїв в роботі серця - $2(9,09 \pm 6,12 \%)$.

При проведенні оцінки біоелектричної активності серця було встановлено, що у дітей з НКМП лівого шлуночка переважали порушення внутрішньошлуночкової провідності серця, серед них частіше зустрі- 
чалась блокада лівої ніжки пучка Гіса (БЛНПГ), яка була зареєстрована у $10(45,45 \pm 10,61 \%)$ дітей. Окрім того враження передньої гілки лівої ніжки пучка Гіса було у $6(27,27 \pm 14,08 \%)$, а задньої у $4(18,18 \pm 12,19 \%)$ дітей. 3 меншою частотою зафіксована неповна блокада правої ніжки пучка Гіса (БПНПГ), яка була у 4 (4,54+4,43 \%) дітей. 3 однаковою частотою спостерігалися синдром WPW $\mathrm{y}$ $2(9,09 \pm 6,12 \%)$ дітей та порушення ритму, у вигляді шлуночкової екстрасистолії у $2(9,09 \pm 6,12 \%)$, а шлуночкова тахікардія була зареєстрована у $3(13,63 \pm 7,31 \%)$ дітей. В ході дослідження також встановлені наступні зміни на ЕКГ: синдром укороченого $\mathrm{PQ}$, без розширення комплексу QRS та нападів пароксизмальної тахікардії.

При оцінці ефективності комплексної терапії з застосуванням препарату кардіометаболічної дії (L-карнітину) у дітей з НКМП ЛШ враховували динаміку неспецифічних та специфічних симптомів, які зустрічалися 3 більшою частотою до проведення терапії. Провівши аналіз динаміки клінічних симптомів у дітей 1 групи, було встановлено, що частота симптомів, таких як швидка втомлюваність, головний біль, серцебиття була достовірно меншою після комплексного лікування 3 використанням L-карнітину $(\mathrm{p}<0,05)$. А такі симптоми, як задишка та запаморочення взагалі були відсутні після лікування.

Водночас в 2 групі, де діти з НКМП отримували лише основну терапію, в динаміці спостерігалося зменшення частоти вказаних симптомів, але достовірної різниці у їх зменшенні після лікування встановлено не було. При порівнянні частоти клінічних симптомів в 1 та 2 групах, було встановлено, що в 1 групі частота симптомів, таких як швидка втомлюваність, головний біль, серцебиття була достовірно меншою, порівняно з 2 групою, $(\mathrm{p}<0,05)$. А скарги на задишку та запаморочення в 1 групі після лікування взагалі були відсутні, на відміну від 2 групи.

Аналіз біоелектричної активності серця у дітей з НКМП показав, що достовірно частіше у даної категорії дітей спостерігалась БЛНПГ та виявлені метаболічні порушення в міокарді. Тому саме ці показники були враховані при оцінці ефективності комплексної терапії. Встановлено, що в 1 групі після лікування спостерігалося достовірне зменшення змін зубця $\mathrm{T}(\mathrm{p}<0,01)$ та були відсутні ознаки депресії сегмента ST, а також було зменшення кількості дітей з БЛНПГ, на відміну від показників до проведення лікування. У 2 групі після проведення терапії, також спостерігалося зменшення вище приведених змін на ЕКГ, але достовірної різниці встановлено не було (p>0,05). При порівнянні показників у двох терапевтичних групах, встановили, що в 
1 групі спостерігалося достовірне зменшення змін зубця $\mathrm{T}(\mathrm{p}<0,01)$ та були відсутні ознаки депресії сегмента ST на відміну від 2 групи.

За період спостереження не відмічено небажаних ефектів від застосування комплексної терапії з додаванням L-карнітину серед дітей, що вказує на його добру переносимість.

Висновки. У дітей з некомпактною кардіоміопатією лівого шлуночка частіше переважали неспецифічні скарг на швидку втомлюваність, головний біль, затримку фізичного розвитку, а серед змін біоелектричної активності серця, частіше реєструвалися неповна блокада лівої ніжки пучка Гіса, депресія сегмента ST та зміна зубця Т. Призначення комплексної терапії з використанням L-карнітину протягом 3 місяців достовірно сприяє зменшенню неспецифічних клінічних симптомів (швидкої втомлюваності, головного болю, запаморочення), зниженню частоти специфічних симптомів (задишки, серцебиття), покращенню функції провідної системи серця та нормалізації метаболічних порушень в міокарді.

\section{Література:}

1. Токарчук Н. І., Вижга Ю. В., Старинець Л. С. Застосування левокарнітину для лікування вторинної кардіоміопатії у дітей раннього віку Современная педиатрия. 2016. № 5. С. 67-71.

2. Марушко Ю.В. Марушко Т.В., Гищак Т.В. Діагностика та удосконалення лікування вторинної кардіоміопатії у дітей. Дитячий лікар. 2017. № 2 (53). С. 12-23.

3. Середюк Н. М., Василюк С. Я., Бензар М. Р. Лівошлуночкова некомпактна кардіоміопатія. Галиџький лікарський вісник. 2016. Т. 21. № 2. C. 134-139.

4. Сорокіна С. І., Шевченко Т. І., Карлінська О. Г. Окремий клінічний випадок спостереження хворого 3 некомпактним міокардом. Клінічна та експериментальна медицина. 2016 . Вип. 4. Т.1. № 13. С. $181-189$.

5. Целуйко В. И. Некомпактная кардиомиопатия лівого желудочка. Ліки Украӥни. 2016. № 6. С. 22-27.

6. Arbustini E. Left Ventricular Noncompaction. A Distinct Cardiomyopathy or a Trait Shared by Different Cardiac Diseases? Jornal of the American college of cardiology. 2015. Vol. 64. №. 17. P. 1840-1850.

7. Flavio Zuccarino. Left Ventricular Noncompaction: Imaging Findings and Diagnostic Criteria. American Journal of Roentgenology. 2015. Vol. 204. № 5. P. 519-530. 